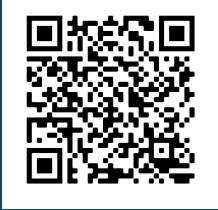

Keywords:

Seeds

Stem-cuttings

Indolebutyric acid

Peloteiro

Rhizobacteria.

Historic:

Received 16/12/2019

Accepted 05/06/2020

+Correspondence: renata.maggioni@ufpr.br
Renata de Almeida Maggionila+, Leandro Marcolino Vieira ${ }^{\text {lb }}$, Sofia Foladori Invernizzile, Antonio Aparecido Carpanezzi ${ }^{2}$, Katia Christina Zuffellato-Ribas ${ }^{1 \mathrm{~d}}$

\section{GERMINATION POTENTIAL AND VEGETATIVE PROPAGATION OF Aegiphila brachiata VELL}

MAGGIONI, R. A.; VIEIRA, L. M.; INVERNIZZI, S.F.; CARPANEZZI, A. A.; ZUFFELLATORIBAS, K. C. Germination potential and vegetative propagation of Aegiphila brachiata Vell. CERNE, v. 26, n. 2, p.222-23I, 2020.

\section{HIGHLIGHTS}

A. brachiata has low germination potential.

The stem-cutting technique is viable for the species.

Stem-cuttings of young trees have better performance for clonal propagation.

The application of indolebutyric acid (IBA) is necessary for rhizogenesis of the species.

\section{ABSTRACT}

The objective of this study was to evaluate the germination potential of Aegiphila brachiata (peloteiro) and its propagation through stem-cuttings, as well as how the age of parental plants and the application indolebutyric acid (IBA) and inoculant of Azospirillum brasilense influence adventitious rooting of the species. Thus, the physical characterization of a seed lot and a germination test were performed, both with or without seed scarification and at three gibberellin concentrations $\left(0,50\right.$ and $\left.100 \mathrm{mg} \cdot \mathrm{L}^{-1} \mathrm{GA} 3\right)$. For stem-cuttings, two experiments were carried out with cuttings, one with young individuals and the other with adult trees. In both experiments, stem-cuttings were submitted to treatments with IBA (0, I500, 3000 and $\left.6000 \mathrm{mg} \cdot \mathrm{L}^{-1}\right)$ and a solution of Azospirillum brasilense (50\% and $100 \%$ of the commercial concentration) for rooting in a greenhouse for 30 days. No seeds germinated and a barrier of radicle emission was identified in the endocarp. The inoculation of stem-cuttings with $A$. brasilense revealed no influence in rhizogenesis. The stem-cutting technique from young trees is recommended for plantlet production of this species (53.75\% rooting), requiring $6000 \mathrm{mg} \cdot \mathrm{L}^{-1}$ IBA application under the conditions that were adopted. Stem-cuttings from adult trees are not recommended for the production of plantlets of peloteiro (Aegiphila brachiata Vell.) due to the low rooting rates (I0\%) and high mortality $(68.33 \%)$. 


\section{INTRODUCTION}

Aegiphila brachiata Vell. (Lamiaceae), popularly known as peloteiro, is an early succession, native forest species that occurs in southeastern and southern Brazil (Harley et al., 2015). Overall, there are few studies about this species; however, its high biomass production, rapid growth in adverse conditions and high resistance to environmental disturbances have been reported, as well as its high potential for the recovery of degraded ecosystems and reforestation.

Although environmental issues have become popular, resulting in an increase on the demand for seedlings of native forest species, the supply of such seedlings is significantly lower than the current and potential demand (Almeida, 2016). The success of seedling production for economic or conservation purposes depends on the knowledge about the germination, initial growth and development of each species, which are directly related to the physiological, physical, health and genetic quality of seeds (Rego et al., 2009).

Nurseries report that $A$. brachiata germination is null, even during long observation periods. According to Santos et al. (2003), the limitation of native species seedlings production is related to difficulties in obtaining seeds, in addition to seed dormancy, which delays germination. Dormancy is a common phenomenon in forest trees of their environment of origin. This process is characterized by a delay in germination caused by endogenous factors (physiological dormancy) related to the embryo itself, or to exogenous factors, such as restricted water entry through the integument (integumentary dormancy) (Carvalho and Nakagawa, 20I2). One of the most commonly used plant growth regulators for germination are gibberellins (GA3), which have an important role in breaking physiological seed dormancy and act on the synthesis of key enzymes such as $\alpha$-amylase; essential for degrading accumulated reserves in the endosperm and embryo, and releasing energy for radicle protrusion (Taiz et al., 2017). Based on this, a coordinated research program is extremely important to determine the efficiency of seminal propagation of this species.

In addition, vegetative propagation might be an excellent alternative for seedling production with environmental purposes, especially for species that have seminal propagation limitations (Carpanezzi and Carpanezzi, 2006; Oliveira and Ribeiro, 20I3), as it can ensure planting uniformity, higher productivity, lower costs, and, above all, year-round plantlet production (Xavier et al., 2009; Wendling et al., 2016).
Among the plant propagation techniques, stemcutting is considered one of the most important since it is economically viable, simple and fast (Zuffellato-Ribas and Rodrigues, 200 I; Hartmann et al., 20I I; Stuepp et al., 20I8). The growth and development of adventitious roots is a complex process, and the age of parental plants is a determining factor for the rhizogenic process, since seedlings from young plants have greater rooting capacity than adult plants (Hartmann et al., 20I I; Stuepp et al., 2018). In addition, the application of root-promoting substances, such as indolebutyric acid (IBA) can accelerate the process of adventitious rooting, as well as root uniformity among stem-cuttings in a nursery (Dias et al., 2012; Pires et al., 2013). Furthermore, products based on plant growth-promoting rhizobacteria (PGPR), such as those of the genus Azospirillum, can produce plant hormones such as auxin (Mariosa et al., 20 I7; Rosa et al., 20I8), and increase root induction and root quality (Melo et al., 20 I2; Vogel, Martinkoski and Ruzicki, 20I4).

To obtain relevant information about $\mathrm{A}$. brachiata seedling production, this study was aimed at evaluating the species seed germination potential and the vegetative propagation viability of stem-cuttings. For that purpose, the effect of scarification and different concentrations of gibberellin on A. brachiata germination were evaluated, as well as the influence of rhizobacteria (Azospirillum brasilense) and indolebutyric acid (IBA) on rooting of cuttings from young and adult $A$. brachiata plants.

\section{MATERIAL AND METHODS}

Experiments were performed to evaluate the germination potential of $A$. brachiata seeds (Experiment I), as well as the efficiency of the stem-cutting technique from plantlets originating from young (Experiment II) and adult $A$. brachiata plants (Experiment III).

Experiment I - Germinative potential of A. brachiata seeds

Fruits were collected from February to March 2019, in Mixed Ombrophilous Forest fragments in the municipalities of Campo do Tenente (25'58 'S and 49.40'

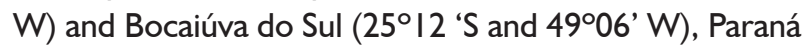
State, Brazil. According to the Köppen classification, the region's climate is temperate $\mathrm{Cfb}$.

Freshly fallen ripe/yellow fruits were collected from the soil, and only those with no visible lesions were selected. The fruits were manually processed, removing pulp with the use of sieves. After extraction, the seeds were dried on filter paper on a laboratory bench at room temperature.

For physical characterization, the moisture content (\%) was determined in four replications of 10 
seeds using the greenhouse method at $105 \pm 3^{\circ} \mathrm{C}$ for 24 hours, and the one thousand seed weight (PMS) was obtained using eight replicates of 100 seeds weighed on an analytical balance with $0.000 \mathrm{Ig}$ precision, according to the methods described by standard Brazilian protocols (Brasil, 2009). The number of seeds per kilogram and the dry biomass of 1000 seeds were also determined.

For the seed water absorption study, four replications of 50 seeds per replicate were used. The seeds were placed in transparent plastic "gerbox" boxes, sank in distilled water and kept in a biochemical oxygen demand (BOD) germinator at a constant temperature of $25^{\circ} \mathrm{C}$. Assessments were performed every three hours for the first 12 hours and then daily until the twentieth day. At the end of each assessment, seeds were removed from the gerbox, placed on sheets of paper to remove excessive external moisture, weighed (precision $0.000 \mathrm{I}$ g) and then placed back in the gerbox and BOD. The water content of the seeds was determined from the moisture content described above.

As a pre-germination treatment, all seeds were sterilized with sodium hypochlorite solution $(2.5 \%$ active chlorine) for five minutes. The experiment followed a completely randomized design in a $2 \times 3$ factorial arrangement, with scarification (yes or no) and gibberellin concentrations ( 0,50 and $100 \mathrm{mg}$.L-I GA3) as factors. Each treatment contained eight replicates and 25 seeds per experimental unit.

For scarification, seeds were sanded in the region opposite from the micropyle with a grinding wheel. Seeds were planted in gerbox boxes, which were disinfected with $70 \%$ alcohol and filled with fine-grained vermiculite, and moistened with $100 \mathrm{~mL}$ of GA3 aqueous solution at different concentrations. After the seeds were planted, gerboxes were placed in a Mangelsdorf germinator at 25 ${ }^{\circ} \mathrm{C}$ and constant light for 150 days. The percentage of seed germination $(\% \mathrm{G})$, germination speed index (GSI) and mean germination time (MGT) were evaluated.

\section{Experiment II - A. brachiata stem-cuttings from} young trees

Herbaceous branches of $A$. brachiata were collected on December 12th, 2018 from a clonal field garden with $\sim 2$ years old and $1.2 \mathrm{~m}$ tall specimens, derived from plantlets produced by stem-cuttings, located in an area belonging to Embrapa Forests in

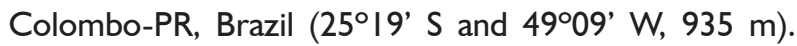
According to the Köppen classification, the region's climate is temperate $\mathrm{Cfb}$ type.

From the collected plant materials, $8 \pm 1 \mathrm{~cm}$ long stem-cuttings were made, with a bevel cut at the base and straight cut at the apex, keeping a pair of leaves reduced in half in the apical portion. The material was then disinfected with $0.5 \%$ sodium hypochlorite for 10 minutes, and then washed in running water for 5 minutes.

After that, the stem-cuttings were treated with IBA hydroalcoholic solutions $(50 \% \mathrm{v} / \mathrm{v})$ for 10 seconds of immersion or with aqueous solutions of Azo Total ${ }^{\circledR}$ (Azospirillum brasilense inoculant, strains AbV5 and AbV6, at the concentration $2 \times 108$ colony forming units $\mathrm{mL}^{-1}$ ) for 15 minutes of immersion, according to the following treatments: TI: control, cuttings without treatment; T2:

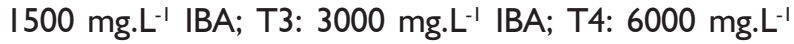
IBA; T5: $50 \%$ Azo Total ${ }^{\circledR}$ (I:I diluted inoculant in water) and T6: $100 \%$ Azo Total ${ }^{\circledR}$ (pure inoculant). The IBA P. A. used was from Sigma Laboratory and Azo Total ${ }^{\circledR}$ was from Total Biotecnologia Indústria e Comércio Ltda.

Stem-cuttings were planted in $53 \mathrm{~cm}^{3}$ polypropylene tubes filled with fine-grained vermiculite, burying $1 / 3$ of their length, and were kept in a greenhouse with intermittent fogging $\left(24^{\circ} \mathrm{C} \pm 2{ }^{\circ} \mathrm{C}\right.$ and $80 \%$ humidity relative air pressure).

The experiment was implemented in a completely randomized design with six treatments and four replications each, containing 20 stem-cuttings per experimental unit. After 30 days the experiment was installed, the following variables were evaluated: percentage of survival (living cuttings without calluses and without roots) (S); rooting percentage (living cuttings, with or without calluses, which had at least I mm long roots) (RP); number of roots per cutting (NR); length of the three largest roots per rooted cutting $(\mathrm{cm})$ (MLR); callogenesis percentage (living, rootless cuttings with undifferentiated mass formation at the base) (C); percentage of leaf retention (living cuttings, with or without roots and callus, which retained original leaves at evaluation time) (LR); percentage of shoots developed (SE).

In this experiment, 50 randomly chosen rooted cuttings were transplanted to 2-liter pots containing commercial substrate made of pine bark and expanded vermiculite to evaluate plantlets survival. After planting, the pots were acclimated in a shade house with $50 \%$ shading and micro sprinkler irrigation (three daily I0-minute irrigations and I 44 L.hour-I.flow) for I 5 days. Subsequently, the plantlets remained in full sun light, with micro sprinkler irrigation (three daily irrigations, 5 minutes duration and flow rate of I44 L.hour-I) for 90 days, when the percentage of living plantlets was evaluated.

Experiment III - A. brachiata stem-cuttings from adult trees

Semi-woody branches of $A$. brachiata were collected on December 12th, 2018 from 20 naturally occurring adult 
trees at $\sim 7 \mathrm{~m}$ high, located in an area at Embrapa Forests,

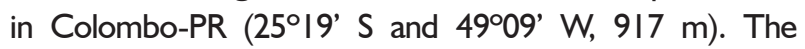
methodology and statistical design used in this experiment were the same as those used for stem-cuttings from young trees, but plantlets were not evaluated after rooting due to the low percentage of rooted cuttings.

\section{Statistical analysis}

Treatment variances were tested for homogeneity the Tukey test $(P<0.01$ and $P<0.05)$, using the Assistat version 7.7. statistical program (Silva, 2019).

\section{RESULTS}

\section{Experiment I - Germinative potential of A. brachiata} seeds

A. brachiata seeds presented $16.43 \%$ moisture content and $568.24 \mathrm{~g}(\mathrm{CV}=2.58 \%)$ for weight of one thousand seeds, resulting in 1760 seeds per kilogram and $474.88 \mathrm{~g}$ of dry biomass of one thousand seeds.

The peloteiro seed water absorption test was performed to identify possible cutaneous impediment to water absorption. The soaking curve in Figure I shows the absorption peak from the first day, followed by slow gradual growth until the eighth day, when the curve stabilizes, with no radicle emission observed.

It was not possible to analyze any of the selected variables for germination (\% G, GSI and MGT), because no radicle emission was observed in any seed after the 150 days interval. Although scarification increased water absorption, we noted that the embryo expanded out of the endocarp in some scarified seeds (Figure 2A), with no forces to emit a radicle and $100 \%$ mortality of scarified seeds by rotting of the embryo after one month of installation.

The peloteiro seeds are surrounded by a thick layer of corneous endocarp (approximately $1.70 \mathrm{~mm}$ ). Internally, this endocarp forms a hard barrier that encloses the micropyle, preventing both embryo expansion and emergence of the primary root (Figure 2B).

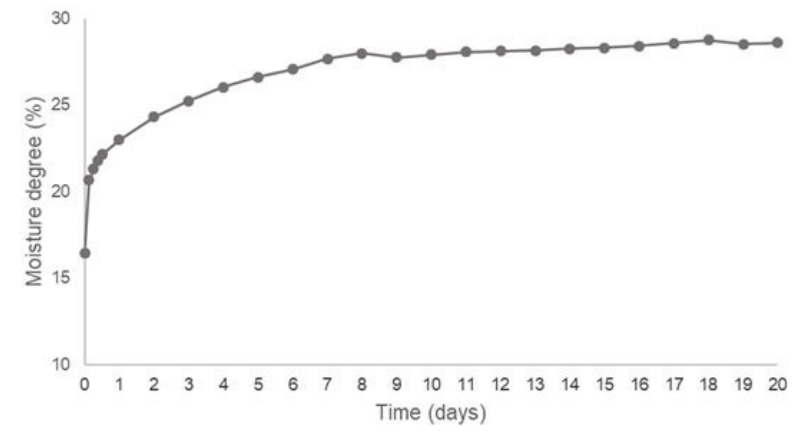

FIGURE I Moisture degree curve of A. brachiata seed soaking in distilled water.

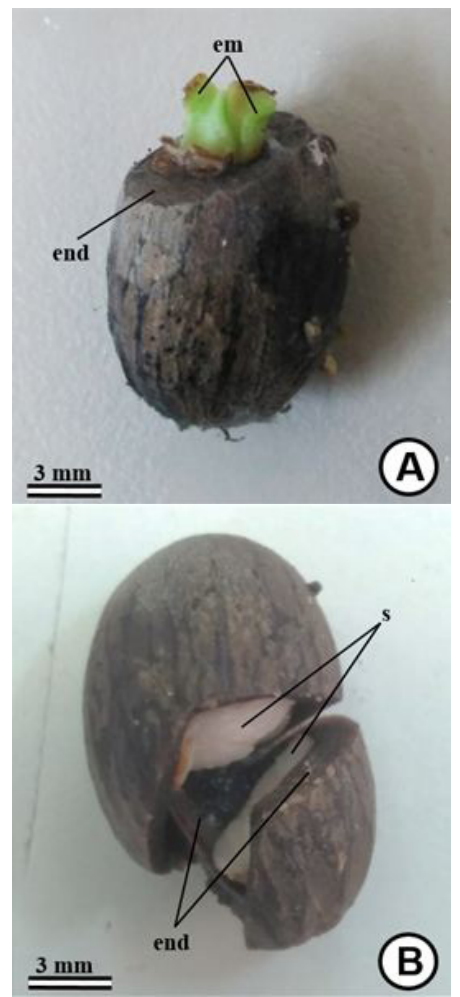

FIGURE 2 Aegiphila brachiata seeds: embryo expanding out of the endocarp (A); endocarp forming a physical barrier (B). em: embryo; end: endocarp; s: seed.

Experiment II - A. brachiata stem-cuttings from young trees

According to ANOVA, there were significant differences $(P<0.0 \mathrm{I})$ for rooting and callogenesis percentage between the different treatments. Figure $3 \mathrm{~A}$ shows a gradual increase in rooting of cuttings as the IBA concentration increases, indicating a positive effect of auxin application, since the control presented only $22.50 \%$ rooting, while the cutting treated with highest IBA concentration (6000 mg. $\left.\mathrm{L}^{-1}\right)$ presented more than the double (53.75\%). A. brasilense inoculation was not efficient for adventitious rooting of $A$. brachiata, presenting inferior or similar results as the control (Figure 3A). Regarding the percentage of callogenesis, there were significant differences $(P<0.0 I)$ in the treatments, confirming an inverse relationship with rooting (Figure 3 ).

Moreover, in the present study, there was no significant difference for the variables number of roots per cutting, length of roots per cuttings, leaf retention and new shoot emissions in the treatments. However, the highest number of roots was observed in the treatment with highest IBA concentration (6000 mg. $\mathrm{L}^{-1}$ ) (Table I), and the largest root length was observed in the treatment with $100 \% \mathrm{~A}$. brasilense inoculant. The leaf retention and new shoots emission variables, also increased as IBA concentration increased (Table I). 

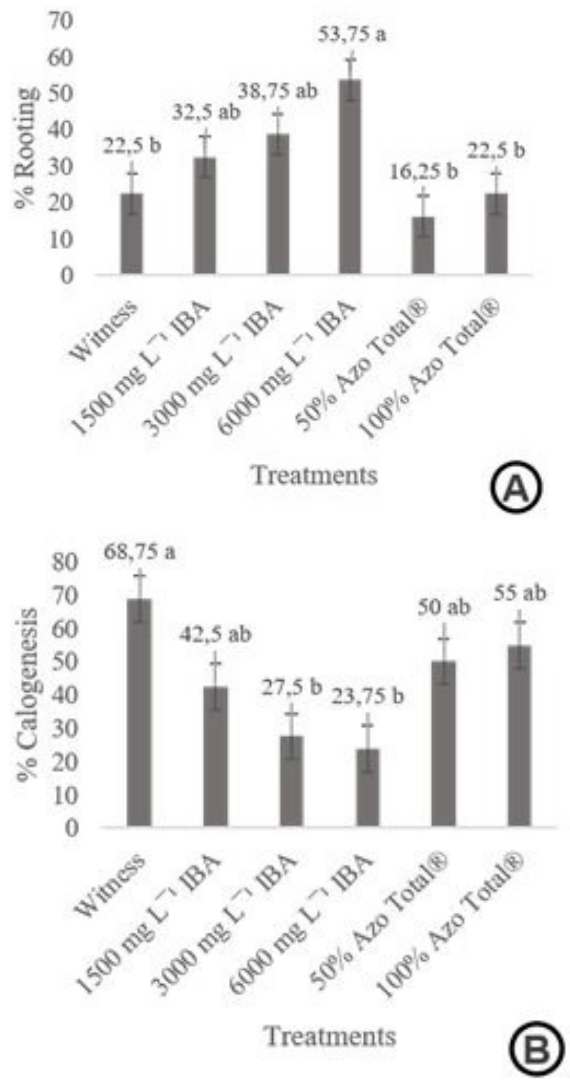

FIGURE 3 Percentage of rooting (A) and callogenesis (B) in stemcuttings from young $A$. brachiata plants in different treatments. TI: control; T2: 1500 mg. L-1 IBA; T3: 3000 mg..-1 IBA; T4: 6000 mg.L-1 IBA; T5: 50\% Azo Total ${ }^{\circledR}$ and T6: $100 \%$ Azo Total ${ }^{\circledR}$. Means followed by the same letter do not differ from each other by the Tukey test at $5 \%$ probability. Vertical bars correspond to the standard error of the mean.

After rooting of the cuttings and plantlet transplantation, there was $80 \%$ survival and rapid growth within 90 days (Figure 4A). Moreover, in just one month after transplanting, flower production was observed in the plantlets (Figure 4B).
TABLE I Number of roots per cutting (NR), length of roots per cuttings (MLR), leaf retention (LR) and new shoots emission (SE) in stem-cuttings from young $A$. brachiata plants after 30 days of planting in different treatments. $\mathrm{CV}$ : Coefficient of variation.

\begin{tabular}{ccccc}
\hline Treatments & NR & $\begin{array}{c}\text { MLR } \\
(\mathrm{cm})\end{array}$ & $\begin{array}{c}\text { LR } \\
(\%)\end{array}$ & $\begin{array}{c}\text { SE } \\
(\%)\end{array}$ \\
\hline Control & $2.39 \mathrm{a}$ & $4.85 \mathrm{a}$ & $48.75 \mathrm{a}$ & $16.25 \mathrm{a}$ \\
$1500 \mathrm{mg} \cdot \mathrm{L}^{-1}$ IBA & $4.76 \mathrm{a}$ & $5.14 \mathrm{a}$ & $56.25 \mathrm{a}$ & $22.50 \mathrm{a}$ \\
$3000 \mathrm{mg} \cdot \mathrm{L}^{-1}$ IBA & $3.54 \mathrm{a}$ & $3.74 \mathrm{a}$ & $57.50 \mathrm{a}$ & $31.25 \mathrm{a}$ \\
$6000 \mathrm{mg} \cdot \mathrm{L}^{-1}$ IBA & $4.90 \mathrm{a}$ & $4.14 \mathrm{a}$ & $72.50 \mathrm{a}$ & $48.75 \mathrm{a}$ \\
$50 \%$ Azo Total ${ }^{\circledR}$ & $2.48 \mathrm{a}$ & $3.39 \mathrm{a}$ & $52.50 \mathrm{a}$ & $17.50 \mathrm{a}$ \\
$100 \%$ Azo Total ${ }^{\circledR}$ & $3.50 \mathrm{a}$ & $6.77 \mathrm{a}$ & $57.50 \mathrm{a}$ & $26.25 \mathrm{a}$ \\
Means & 3.59 & 4.67 & 57.50 & 27.08 \\
CV $(\%)$ & $39.4 \mathrm{I})$ & 39.64 & 27.00 & 69.49 \\
\hline
\end{tabular}

Experiment III - A. brachiata stem-cuttings from adult trees

In this experiment, according to ANOVA, there were significant differences $(P<0.0 \mathrm{I})$ for the rooting percentage variable only. There was a gradual increase in rooting as IBA concentration increased. However, the results are unsatisfactory, since the highest rooting percentage was $10 \%$ at $6000 \mathrm{mg} \cdot \mathrm{L}^{-1}$. There was no rooting in the control and in the Azo Total ${ }^{\circledR}$ inoculant treatments (Figure 5).

Table 2 shows that there was no significant difference for any of the other variables in the different treatments, according to the analysis of variance. However, there was an increase in the number and length of roots as the concentration of IBA augmented.

Overall, the percentages of callogenesis and survival of cuttings were low in all treatments, as well as the induction of new shoots (Table 2). In addition, Table 3 shows a low percentage of leaf retention (overall average of $30 \%)$.

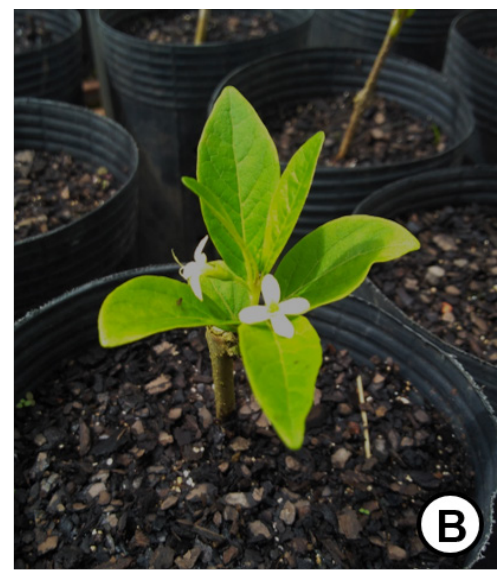

FIGURE 4 A. brachiata: high plantlet biomass production 90 days after transplantation (A); flowering detail of plantlets 30 days after transplantation (B). 


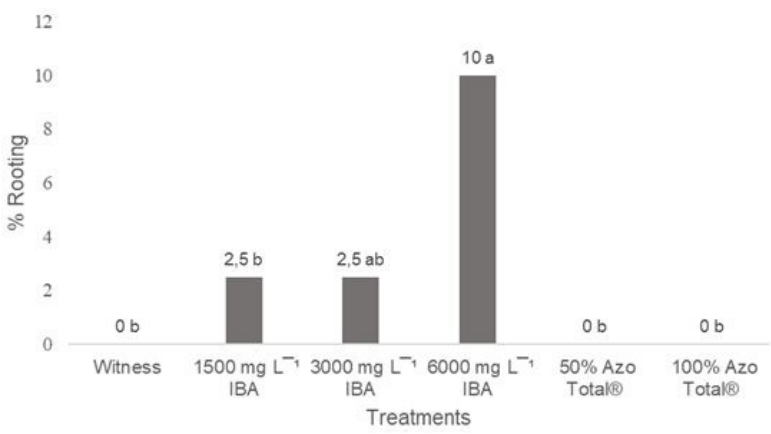

FIGURE 5 Rooting percentage in stem-cuttings from adult A. brachiata plants in different treatments. Means followed by the same letter in the column do not differ statistically from each other by the Tukey test at $5 \%$ probability.

TABLE 2 Number of roots per cuttings (NR), length of roots per cuttings (MLR), callogenesis percentage (C), survival percentage (S), new shoots emission (SE) and leaf retention (LR) in cuttings from adult $A$. brachiata trees after 30 days of planting under different treatments. $\mathrm{CV}$ : Coefficient of variation.

\begin{tabular}{|c|c|c|c|c|c|c|}
\hline Treatments & NR & $\begin{array}{l}\text { MLR } \\
(\mathrm{cm})\end{array}$ & $\begin{array}{c}C \\
(\%)\end{array}$ & $\begin{array}{c}\mathrm{S} \\
(\%)\end{array}$ & $\begin{array}{c}\text { SE } \\
(\%)\end{array}$ & $\begin{array}{l}\text { LR } \\
(\%)\end{array}$ \\
\hline Control & $0.00 \mathrm{a}$ & $0.00 \mathrm{a}$ & $8.75 \mathrm{a}$ & $25.00 \mathrm{a}$ & $8.75 \mathrm{a}$ & $28.75 \mathrm{a}$ \\
\hline $1500 \mathrm{mg} \mathrm{L}^{-1}$ IBA & $1.25 \mathrm{a}$ & $0.35 \mathrm{a}$ & $12.50 \mathrm{a}$ & $16.25 \mathrm{a}$ & $3.75 \mathrm{a}$ & $26.25 \mathrm{a}$ \\
\hline $3000 \mathrm{mg} \mathrm{L}^{-1}$ IBA & $1.75 \mathrm{a}$ & $0.60 \mathrm{a}$ & $6.25 \mathrm{a}$ & $11.25 \mathrm{a}$ & $3.75 \mathrm{a}$ & $20.00 \mathrm{a}$ \\
\hline $6000 \mathrm{mg} \mathrm{L}^{-1}$ IBA & $2.00 \mathrm{a}$ & $1.33 \mathrm{a}$ & $12.50 \mathrm{a}$ & $18.75 \mathrm{a}$ & $6.25 \mathrm{a}$ & $41.25 \mathrm{a}$ \\
\hline $50 \%$ Azo Total ${ }^{\circledR}$ & $0.00 \mathrm{a}$ & $0.00 \mathrm{a}$ & $12.50 \mathrm{a}$ & $26.25 \mathrm{a}$ & $5.00 \mathrm{a}$ & $38.75 \mathrm{a}$ \\
\hline I00\% Azo Total ${ }^{\circledR}$ & $0.00 \mathrm{a}$ & $0.00 \mathrm{a}$ & $13.75 \mathrm{a}$ & $11.25 \mathrm{a}$ & $3.70 \mathrm{a}$ & $25.00 \mathrm{a}$ \\
\hline Means & 0.83 & 0.38 & 11.04 & 18.12 & 5.21 & 30.00 \\
\hline CV (\%) & 206.88 & 187.48 & 93.81 & 63.62 & 89.80 & 43.92 \\
\hline
\end{tabular}

Means followed by the same letter in the column do not differ statistically from each other by the Tukey test at $5 \%$ probability

\section{DISCUSSION}

\section{Experiment I - Germinative potential of A. brachiata seeds}

The main purpose of physical seed analysis is to determine plot quality and sowing and storage value, since quality is used as a standard of excellence for certain attributes that will determine seed germination performance (Brüning et al., 20ll). There have been no studies about seed behavior regarding physical description or germination for $A$. brachiata.

Here, the 1000 seed weight of $A$. brachiata was $568.24 \mathrm{~g}$, with 1760 seeds per kilogram. In comparison, Aegiphila integrifolia, a common species of the genus, has much smaller seeds, with 26,075 seeds per kilogram (Frigieri et al., 2016). According to Gonçalves et al. (20I3), biometric analyses of seeds are very important because they assist in determing the mechanisms of dispersion, as well as to differentiate species in the same genus and to evaluated the genetic variability for such traits within and among populations.

In the present study, the seeds of $A$. brachiata presented a moisture content of $16.43 \%$. There are no reports in the literature that describe the tolerance of the species to desiccation and storage. However, Aegiphila sellowiana seeds are described as having intermediate desiccation tolerance (Mayrinck et al., 2016), presenting up to $14.7 \%$ water content (Nascimento et al., 20I7). The response of seeds varies widely from one species to another, which leads some authors to postulate levels of recalcitrance or degrees of desiccation tolerance, ranging from highly intolerant to highly tolerant (Barbedo et al., 20I3). Thus, further studies are needed to develop technology for efficient production and storage of $A$. brachiata seeds.

The process of seed germination begins with water imbibition, which activates the metabolism of the embryo, and in turn emits the radicle that develops until the seedling is established. This process occurs according to a three-phase immersion pattern. The first phase is characterized by rapid water absorption, usually in the first two hours, due to the difference in water potential between the seed and the medium (Bewley and Black, 1994). Although rapid absorption during the first hours of immersion (Figure I) was observed herein, the water content of seeds only increased from $16.43 \%$ to $23 \%$. According to Carvalho and Nakagawa (20I2), the germination of seeds occurs when the water content varies from 35 to $40 \%$ in phase I of the immersion process. These percentages are almost the double of what was observed in the present study, indicating that the seed cover of $A$. brachiata may be considerably impermeable, hindering water absorption.

During phase II of the immersion process, there is intense transport of broken substances in phase I from the reserve tissue to the meristematic tissue, and stabilization of water absorption. In phase III, a new peak of water absorption occurs as a consequence of germination (Bewley \& Black, 1994). Moreover, even though $A$. brachiata seed water absorption stabilized in the second phase, until the twentieth day, seeds did not enter the third phase of the soaking process, with no radicle emission observed. Such fact confirms a restricted water absorption of the A. brachiata seeds, such as tegument dormancy.

Santos et al. (2003), discussed that the propagation of native species is often limited by seed dormancy, which delays germination. One of the main reasons for seed dormancy starts with the restriction of water by the integument. In the present study, the lack 
of $A$. brachiata germination is associated with resistance imposed by the endocarp not only on water absorption, but on radicle protrusion.

A similar scenario was observed for Bertholletia excelsa (Brazil-nuts) seeds, which presents a hard endocarp outside the seed and low water permeability, which confers resistance to radicle emission. In Brazilnut germination, seeds with endocarps take 12 to 18 months to germinate, while seeds without endocarps germinate at 20 to 30 days (Maués et al., 20I5). Based on this, new studies should be performed in which the endocarp is removed for the germination of $A$. brachiata seeds. However, this is a delicate process and requires practice to avoid damaging the seeds.

\section{Experiment II - A. brachiata stem-cuttings from} young trees

As shown, there was a positive effect of auxin application on the adventitious rooting of $A$. brachiata. When the endogenous level of auxin is insufficient in a plant, the application of more stable synthetic auxins, such as IBA, is important to promote adequate hormonal balance that favors root induction (Pires et al., 20I3). However, the optimal concentration of these plant growth regulators varies according to the level of endogenous indoleacetic acid (IAA) in each species (Erturk et al., 20 I0; Hartmann et al., 20I I), the age of the parent plant (Stuepp et al., 2018), the time of propagule collection (Oliveira and Ribeiro, 2013), the substrate (Ari, 2016), among other factors.

Some authors report the potential effects of rhizobacteria on rooting, as these microorganisms are capable of producing endogenous auxins (IAA) in plants (Erturk et al., 2010; Mariosa et al., 2017). Evidencing the insufficiency of endogenous levels of auxin in the studied species, the use of Azo Total ${ }^{\circledR}$ did not present a positive effect on root induction. These results suggest low susceptibility of the species to the penetration and colonization of these microorganisms, as it did not respond to inoculation.

The percentage of callogenesis was inversely proportional to adventitious rooting. Callus formation may indicate low juvenility of the propagated material, favorable environmental conditions for rooting and balance between endogenous concentrations of auxin and cytokine (Hartmann et al., 20 I I, Ikeuchi et al., 20I3; Nasri et al., 2015). It is known that radical formation can occur from a callus. This rhizogenesis occurs when the emission of adventitious roots is preceded by an intermediate stage, in which irregular parenchyma cell masses are formed in different lignification stages
(Hartmann et al., 20II). Thus, it is likely that the application of IBA accelerated cell differentiation in peloteiro stem-cuttings, contributing to the emergence of adventitious roots from undifferentiated parenchyma cells, in a process called indirect rhizogenesis, since all rooted cuttings presented calluses.

The highest number of roots was observed in the treatment with the highest IBA concentration, demonstrating the efficiency of this plant growth regulator. Additionally, although it was not efficient for root induction of the species, its noted a potential use of $A$. brasiliensis in the development of roots, which can improve survival of plantlets in the field. For with IBA could aid in root induction and rhizobacteria in root development, further studies are needed to prove the efficiency of the combination IBA and rhizobacteria. Besides the formation and growth of roots, the variables number of roots per cuttings and average root length are extremely important, as they ensure the success of plantlets after field plantings. Plantlets with higher quality root systems tend to survive longer in the field, develop better fixation to the soil, and contribute to more efficient water and nutrient absorption (Reis et al., 2000).

The application of IBA also favored leaf retention and emission of new shoots. The importance of leaf retention, that is, the maintenance of leaves at the time of cutting, is directly related to root induction, mainly because this organ helps supply certain compounds, i.e., carbohydrates, auxins and rooting cofactors, which can be translocated via the stem-based phloem, thereby stimulating root formation (Fragoso et al., 20I5).

According to Hartmann et al. (20II), the advantages of vegetative propagation are related to the establishment of plantations from superior genotypes, with genetic characteristics identical to the matrix plant (clone), allowing homogeneity of production and accelerated flowering. Thus, considering the problems mentioned above regarding seminal propagation of Experiment I, the good performance of plantlet survival and growth results after transplanting not only reinforce the efficiency of the cutting technique for plantlet production, but also emphasize that this technique successfully reduced the young period, with accelerated flowering and subsequent fruit production.

Experiment III - A. brachiata stem-cuttings from adult trees

The results were unsatisfactory for adult tree stemcuttings due to the low percentages of rooting even with IBA application and the absence of rooting in the control and treatments with Azo Total ${ }^{\circledR}$ inoculants. Some authors report that rhizobacteria can produce endogenous auxins (IAA) in 
plants, assisting in rooting (Erturk et al., 20 I0; Mariosa et al., 2017). However, the results obtained in the present work disagree with the literature, suggesting that the level of endogenous auxin in the plant was insufficient to promote root induction, and that the species has low susceptibility to penetration and colonization of rhizobacteria, as it did not respond to inoculation.

When native species seedlings are produced for environmental purposes, genetic variability is essential and seedlings should be collected from as many tree matrices as possible (Carpanezzi and Carpanezzi, 2006). Thus, the main objective of using adult propagules in vegetative propagation is to obtain high genetic variability by representing distinct adult trees, i.e., different genotypes. However, the major consequence of maturation in woody species is reduced regenerative capacity, reflected directly in root induction and rooting vigor, that is, propagules from adult plants have lower rooting capacity than those from young plants. This is because young plant presents physiological conditions, such as hormonal balance, that favor rooting (Hartmann et al., 20II; Dias et al., 2012; Wendling et al., 2014; Stuepp et al., 2018). Thus, the maturation state of vegetative propagules may have negatively influenced the adventitious rooting of $A$. brachiata, since there was no root induction in the control treatment.

The exogenous application of auxins, such as IBA, positively affects adventitious rooting, promoting the development of a vigorous root system with root quality and quantity, increasing rooting percentage, uniformity and speed (Dias et al., 20 I2; Saucer et al., 20 I3). Although there was no significant difference, there was an increase in the number and length of roots with IBA application, reinforcing the potential of this plant regulator in the adventitious rooting of the species.

Analyzing the low values found for the other variables (callogenesis, survival, mortality, new shoot emission and leaf retention), these results are possibly related to insufficient amount of carbohydrates in stem-cuttings, resulting from the lignification stage caused by using adult propagules and contributing to low rooting rates and high cutting mortality (overall average of $68.33 \%$ ).

Leaf retention is important for rooting and survival of cuttings. The auxin gradient in the segments is an important factor for the induction of the abscission zone, with low endogenous auxin levels leading to the formation of the abscission layer at the base of the leaf petiole, which is sensitive to the auxins/ethylene balance, causing early leaf fall, as auxin suppresses the ethylene effect (Ito; Nakano, 20I5; Taiz et al. al., 20I7; MarasekCiolakowska et al., 2020).
This fact is justified by the high percentage of leaf retention (4I.25\%) observed in the treatment with the highest IBA concentration $\left(6000 \mathrm{mg} \cdot \mathrm{L}^{-1}\right)$ application, combined with the absence of rooting in the control treatment, indicating that the endogenous levels of auxin were insufficient to promote rooting, as well as to ensure cutting survival. Thus, of the use of stem-cuttings from adult trees is not indicated for vegetative propagation of A. brachiata due to low rooting rates and high mortality.

\section{CONCLUSIONS}

A. brachiata seeds have low germination potential due to a physical barrier of the endocarp, which can prevent water absorption as well as radicle emission. Stemcuttings of young trees are feasible and recommended to produce peloteiro plantlets, requiring exogenous addition of indolebutyric acid (IBA), with the $6000 \mathrm{mg} \cdot \mathrm{L}^{-1}$ concentration being the most efficient. The inoculation of stem-cuttings with Azospirillum. brasilense revealed no influence in rhizogenesis. Stem-cuttings obtained from adult trees are not indicated for $A$. brachiata clonal propagation.

\section{ACKNOWLEDGMENTS}

We thank the Coordination for the Improvement of Higher Education Personnel (CAPES), for the financial support. And to Ph.D. Antonio Carlos Nogueira for all contribution on development this work.

\section{REFERENCES}

ARI, E. Effects of different substrates and IBA concentrations on adventitious rooting of native Vitex agnus-castus $L$. cuttings. Acta Scientiarum Polonorum, v. I5, n. 2, p. 27-4I, 2016.

ALMEIDA, D.S. Recuperação ambiental da mata atlântica (online). 3. ed. Ilhéus, BA: Editus, 2016. 182p.

BARBEDO, C.J.; CENTENO, D.C.; FIGUEIREDO-RIBEIRO, R.C.L. Do recalcitrant seeds really exist? Hoehnea, v.40, p.583-593, 2013.

BEWLEY, J.D.; BLACK, M. Seeds: physiology of development and germination. 2. ed. New York: Plenum Press, 1994. 445p.

BRASIL. Ministério da Agricultura, Pecuária e Abastecimento. Regras para análise de sementes. Ministério da Agricultura, Pecuária e Abastecimento. Secretaria de Defesa Agropecuária. Brasília: MAPA/ACS, 2009. 395p.

BRÜNING, F.O.; LÚCIO, A.D.; MUNIZ, M.F. B. Padrões para germinação, pureza, umidade e peso de mil sementes em análises de sementes de espécies florestais nativas do Rio Grande do Sul. Ciência Florestal, v. 2 I , n. 2, p. I93-202, 20 I I.

CARPANEZZI, A.A.; CARPANEZZI, O.T.B. Espécies nativas recomendadas para recuperação ambiental no Estado do Paraná, em solos não degradados. Colombo: Embrapa Florestas, 2006. 52p. (Embrapa Florestas. Documentos, I36). 
CARVALHO, N. M.; NAKAGAWA, J. Sementes: ciência tecnologia e produção. 5.ed. Jaboticabal: FUNEP, 20I2. 590p.

DIAS, C.D.; OLIVEIRA, L.S.; XAVIER, A.; WENDLING, I. Estaquia e miniestaquia de espécies florestais lenhosas do Brasil. Pesquisa Florestal Brasileira, v. 32, n. 72, p. 453462,2012

ERTURK, Y.; ERCISLI, S.; HAZNEDAR, A.; CAKMAKCI, R. Effects of plant growth promoting Rhizobacteria (PGPR) on rooting and root growth of kiwifruit (Actinidia deliciosa) stem cuttings. Biological Research, v. 43, p. 91-98, 2010.

FRAGOSO, R.O.; WITT, N.G.P.M.; OBRZUT, V.V.; VALÉRIO, S.; ZUFFELLATO-RIBAS, K.C.; STUEPP, C.A. Maintenance of leaves and indolebutyric acid in rooting of juvenile Japanese Flowering Cherry cuttings. Revista Brasileira de Ciências Agrárias, v. 10, n. I, p. 97-101, 2015.

FRIGIERI, F. F.; IWANICKI, N. S.; GANDARA, F. B.; FERRAZ, E. M.; ROMÃO, G. O.; COLETTI, G. F.; SOUZA, V. C.; MORENO, M. A. Guia de plântulas e sementes da Mata Atlântica do estado de São Paulo. Piracicaba: IPEF, 2016, 99 p.

GONÇALVES, L.G.V.; ANDRADE, F.R.; MARIMON JUNIOR, B.H.; SCHOSSLER, T.R.; LENZA, E.; MARIMON, B.S. Biometria de frutos e sementes de mangaba (Hancronia speciosa Gomes) em vegetação natural na região de Mato Grosso, Brasil. Revista de Ciências Agrárias, v. 26, n. I, p. $31-40,2013$

HARLEY, R. et al. 2015. Lamiaceae in Lista de Espécies da Flora do Brasil. Jardim Botânico do Rio de Janeiro. Disponivel em: <http://floradobrasil.jbrj.gov.br/jabot/ floradobrasil/FB8104>.

HARTMANN, H.T.; KESTER, D.E.; DAVIES JR, F.T.; GENEVE, R.L. Plant propagation: principles and practices. 8. ed. Boston: Prentice Hall, 2011. 915p.

IKEUCHI, M; SUGIMOTO, K.; IWASE, A. Plant Callus: Mechanisms of Induction and Repression. The Plant Cell, v. 25 , p. 3159-3173, 2013

ITO, Y.; NAKANO, T. Development and regulation of pedicel abscission in tomato. Frontiers Plant Science, v.8, p.442, 2015.

MARASEK-CIOLAKOWSKA, A., SANIEWSKI, M., DZIURKA, M., KOWALSKA, U., GÓRAJ-KONIARSKA, J., UEDA, J., \& MIYAMOTO, K. Formation of the Secondary Abscission Zone Induced by the Interaction of Methyl Jasmonate and Auxin in Bryophyllum calycinum: Relevance to Auxin Status and Histology. International Journal of Molecular Sciences, v. 2I, n. 8, p. 2784, 2020.

MARIOSA, T.N.O.; MELLONI, E.G.P.; MELLONI, R.; FERREIRA, G.M.R.; SOUZA, S.M.P.; SILVA, L.F.O. Rizobactérias e desenvolvimento de mudas a partir de estacas semilenhosas de oliveira (Olea europeae L.). Revista Ciências Agrárias, v. 60 , n. 4 , p. 302-306, 2017.
MAUÉS, M.; KRUG, C.; WADT, L.H.O.; DRUMOND, P.M.; CAVALCANTE, M.C.; SANTOS, A.C.S. A castanheirado-Brasil: avanços no conhecimento das práticas amigáveis à polinização. Rio de Janeiro: Funbio, 2015, 84p.

MAYRINCK, R.C.; AFONSO, T.A.V.; DAVIDE, A.C. Classificação fisiológica de sementes florestais quanto à tolerância à dessecação e ao comportamento no armazenamento. Cerne, v. 22, n. I, p. 85-92, 2016.

MELO, L.C.; OLIVEIRA, C.V.; MANFREDI, C.; BALDANI, V.L.D.; FERREIRA, J.S. Efeito de bactérias na promoção do enraizamento em clone de eucalipto. Enciclopédia Biosfera, v. 8, n.I5, p.736-748, 2012.

NASCIMENTO, P.; LAFETA, B. O.; FERREIRA, J. C. B. Pregermination treatments and their relation with Aegiphila sellowiana Cham seeds germination. Australian Journal of Basic and Applied Sciences, v. I I, n. 5, p. 69-79, 2017.

NASRI, F.; FADAKAR, A.; SABA, M.K.; YOUSEF, B. study of indole butyric acid (IBA) effects on cutting rooting improving some of wild genotypes of damask roses (Rosa damascena Mill.). Journal of Agricultural Sciences, v. 60, n. 3, p. 263-275, 2015.

OLIVEIRA, M. C.; RIBEIRO, J. F. Enraizamento de estacas de Euplassa inaequalis (Pohl) Engl. de mata de galeria em diferentes estações do ano. Bioscience Journal, v. 29, p. 991-999, 2013

PIRES, P. P.; WENDLING, I.; BRONDANI, G. Ácido indolbutírico e ortotropismo na miniestaquia de Araucaria angustifolia. Revista Árvore, v. 37, n. 3, p. 393-399, 2013.

REGO, S.S.; NOGUERIA, A.C.; KUNIYOSHI, Y.S.; SANTOS, A.F. Germinação de sementes de Blepharocalyx salicifolius (H.B.K.) Berg. em diferentes substratos e condições de temperatura, luz e umidade. Revista Brasileira de Sementes, Brasília, v. 31, n. 2, p. 212- 220, 2009.

REIS, J.M.R.; CHALFUN, N.N.; LIMA, L.C.O.; LIMA, L.C. Efeito do estiolamento e do ácido indolbutírico no enraizamento de estacas do porta-enxerto Pyrus calleryana Dcne. Ciência Agrotécnica, v. 24, n. 4, p. 931-938, 2000.

ROSA, D.D.; VILLA, F.; DA SILVA, D.F; CARBARI, F. Rooting of semihardwood cuttings of olive: indolbutyric acid, calcium and Azospirillum brasilense. Comunicata Scientiae, v. 9, n. I, p. 34-40, 2018.

SANTOS, M.R.A.; PAIVA, R.; GOMES, G.A.C.; PAIVA, P.D.O.; PAIVA, L.V. Estudos sobre superação de dormência em sementes de Smilax japecanga Grisebach. Ciência e Agrotecnologia, v. 27, n. 2, p. 319-324, 2003.

SAUER, M.; ROBERT, S.; KLEINE-VEHN, J. Auxin: simply complicated. Journal of Experimental Botany, v. 64, n. 9, p. 2565-2577, 2013 
SILVA, F. A. S. ASSISTAT - Assistência Estatística - versão 7.7 beta (pt). Programa computacional. Universidade Federal de Campina Grande Campus de Campina Grande-PB DEAG/CTRN. 2014. Disponível em: <http://www.assistat. com/>. Acesso em: 10 fev. 2019.

STUEPP, C. A.; WENDLING, I.; XAVIER, A.; ZUFFELLATORIBAS, K. C. Vegetative propagation and application of clonal forestry in Brazilian native tree species. Pesquisa agropecuária brasileira, v. 53, n. 9, p. 985-1002, 2018.

TAIZ, L.; ZEIGER, E.; MØLLER, I. M.; MURPHY, A. Fisiologia e Desenvolvimento Vegetal. 6 ed. Porto Alegre: Artmed. 2017.888 p.

VOGEL, G. F; MARTINKOSKI, L.; RUZICKI, M. Efeitos da utilização de Azospirillum brasilense em poáceas forrageiras: importâncias e resultados. Agropecuária Científica no Semiárido, v. 10, n. I, p. I-6, 2014.
WENDLING, I.; STUEPP, C. A.; ZUFFELLATO-RIBAS, K. C. Araucaria clonal forestry: types of cuttings and mother tree sex in field survival and growth. Cerne, v. 22, n. I, p. 1926, 2016.

WENDLING, I.; TRUEMAN, S.J.; XAVIER, A. Maturation and related aspects in clonal forestry - Part I: concepts, regulation and consequences of phase change. New Forests, v. 45, p. 449-47I, 2014.

XAVIER, A.; WENDLING, I.; SILVA, R. L. Silvicultura clonal: princípios e técnicas. Viçosa: Ed UFV, 2009. 272p.

ZUFFELLATO-RIBAS, K. C.; RODRIGUES, J. D. Estaquia: uma abordagem dos principais aspectos fisiológicos. Curitiba: [K. C. Zuffellato-Ribas], 200I. 39p 